WE examined the tumor necrosis factor $\alpha$ (TNF $\alpha)$ induced apoptosis of vascular endothelial cells from the standpoint of ion channels. Cultured vascular endothelial cells from bovine carotid artery were used. Apoptosis was determined by a propidium iodide assay. Treatment of the endothelial cells with TNF $\alpha$ and cycloheximide for $6 \mathrm{~h}$ induced nuclear fragmentation in a TNF $\alpha$ dose-dependent manner (1-10 $\mathrm{ng} / \mathrm{ml})$. Concomitant treatment of endothelial cells with TNF $\alpha$ at a dose of $10 \mathrm{ng} / \mathrm{ml}$ and cyclohex imide at a dose of $10 \mu \mathrm{g} / \mathrm{ml}$ elicited endothelial cell apoptosis as high as $23.4 \pm 4.1 \%$ at $6 \mathrm{~h}$ afte $\mathrm{r}$ adminis tration. However, $10 \mathrm{ng} / \mathrm{ml} \mathrm{TNF} \alpha$ alone elicited a little apoptosis at $6 \mathrm{~h}$ after its administration (\% apoptosis $=4.1 \pm 0.8 \%)$. Cycloheximide $(10 \mu \mathrm{g} / \mathrm{ml})$ did not induce apoptosis at all. Concomitant treatment of endothelial cells with $1 \mathrm{~m} \mathrm{~mol} / 1$ of 4,4-diis othiocyanatostilbene-2,2-disulfonic acid, which is a chloride bicarbonate exchanger blocker, partially inhibited the TNF $\alpha$ and cyclohexim ide-in duced endoth elial cell apoptosis. On the other hand, endothelial cell apoptosis due to TNF $\alpha$ and cycloheximide was completely inhibited by benzyloxycarbonyl-Asp- $\mathrm{CH}_{2} \mathrm{OC}(\mathrm{O})$ 2,6-dichlorobenzene $(50 \mu \mathrm{mol} / 1)$, an inhibitor of caspase. Moreover, pyrrolidine dithiocarbanate, an inhibitor of nuclear factor kappa $B(N F-\kappa B)$, also suppressed endothelial cell apoptosis induced by TNF $\alpha$ and cycloheximide completely. These findings suggest that the endothelial cell apoptosis induced by TNF $\alpha$ and cyclohexim ide is closely related to not only chloride ions, but also both NF- $\kappa B$ and caspase activation. That is to say, there is a possibility that chloride ions or bicarbonate $(\mathrm{pH})$ may play an important role in signal transduction such as NF- $k B$ and caspase activation in the apoptosis induced by TNF $\alpha$ and cycloheximide.

Key words: Apoptosis, Tumor necrosis factor, Chloride bicarbonate exchanger, Endothelial cells, Apoptosis

\section{A possible involvement of ion transporter in tumor necrosis factor $\alpha$ and cycloheximide-induced apoptosis of endothelial cells}

\author{
Hiroshi Fujita ${ }^{1,2, C A}$, Ikuo Morita ${ }^{2}$ and \\ Sei-itsu Murota ${ }^{2}$
}

${ }^{1}$ Department of Internal Medicine, Tokyo

Metropolitan Bokutou General Hospital, Sumida-ku, Tokyo; and ${ }^{2}$ Department of Physiological Chemistry, Graduate School, Tokyo Medical and Dental University, 1-5-45 Yushima, Bunkyo-ku, Tokyo 113, Japan

${ }^{\mathrm{CA}}$ Corresponding Author

Present Address: Department of Internal Medicine,

Tokyo Metropolitan Bokutou General Hospital, 4-23-15 Koutoubashi, Sumida-ku, Tokyo 130-8575, Japan

Tel: $(+81) 336336151$

Fax: (+81) 336336173

\section{Introduction}

Apoptosis (programmed cell death) is a fundamental process in embryogenesis, tissue hemostasis, and immune system maturation. ${ }^{1}$ Its deregulation may have important implications for carcinogenesis and immune system disorders. It has been reported that apoptosis plays an important role in various pathophysiological conditions such as hypoxia/reperfusion injury, radiation pneumonitis, etc. ${ }^{2,3}$ Endothelial cell apoptosis has been observed when endothelial cells are exposed to basic fibroblast grow th factor depletion. ${ }^{4}$ Lung injury such as pulmonary edema due to radiation is based on endothelial cell apoptosis. ${ }^{3}$ Moreover, lupus anticoagulant-induced apoptosis of endothelial cells with recognition of annexin $\mathrm{V}$ has been reported. ${ }^{5}$ It was suggested that apoptosis of endothelial cells may be responsible for the vasculitis associated with systemic lupus erythematosus. Thus, endothelial cell apoptosis may cause the various pathological conditions.

Tumor necrosis factor $\alpha$ (TNF $\alpha)$ is an inducer of apoptosis in various cells as well as an inflammatory cytokine. TNF $\alpha$ activated the Fas-associated protein with death domain (FADD) through the receptor of TNFo, subsequently caused the activation of the caspase, resulting in apoptosis. ${ }^{6}$ TNF $\alpha$ receptor binding protein, TRAF2, elicited nuclear factor kappa B (NF- $\mathrm{B}$ ) activation, which has an inhibitory action on caspase activity. ${ }^{7}$ On the other hand, ceramide, which is produced from sphigomyelin due to activated sphingomyelinase by TNFo, can also induce both NF$\kappa \mathrm{B}$ and apoptosis. ${ }^{8}$

In the present study, we show that TNF $\alpha$ can induce apoptosis of endothelial cells concomitantly with cycloheximide. This apoptosis was inhibited by 
an NF-KB inhibitor such as pyrrolidine dithiocarbonate (PDTC) or a caspase inhibitor. Moreover, we will demonstrate that 4,4-diisothiocyanato stilbene-2,2-disulfonic acid (DIDS), a blocker of chloride bicarbonate exchanger, can prevent TNF $\alpha$ and cycloheximideinduced apoptosis of endothelial cells.

\section{Materials and methods}

\section{Reagents}

Human recombinant TNFo w as purchased from Endogen Inc. (NY) DIDS, 5- $N, \quad N$-dimethyl amiloride, propidium iodide (PI), PDTC, $N$-acetyl cysteine (NAC) and anthracene carboxylic acid were purchased from Sigma Co. Ltd (St. Louis, MO). BenzyloxycarbonylAsp- $\mathrm{CH}_{2} \mathrm{OC}(\mathrm{O})-2,6$-dichlorobenzene (zD-dcb) was purified as described previously.

\section{Endothelial cell culture}

Endothelial cells were isolated from freshly excised bovine carotid arteries as described previously. ${ }^{10}$ Briefly, endothelial cells were obtained by lightly scraping the intimal surface of longitudinally opened vessels. The cells were then seeded into $60 \mathrm{~mm}$ dishes (Falcon Labware, Division of Becton Dickinson and Company, Lincoln Park, NJ) in a grow th medium containing minimum essential medium (MEM) (Gibco Laboratories, Grand Island, NY) supplemented with $20 \%$ heat-inactivated fetal calf serum (FCS) (Intergen Co. Purchase, NY), penicillin, and streptomycin $(2 \%$ total medium volume, Gibco Laboratories) and subcultured in a $10 \%$ FCS-containing MEM. Cultures were maintained in a humidified incubator at $37^{\circ} \mathrm{C}$ under $95 \%$ air $/ 5 \% \mathrm{CO}_{2}$, and were identified as endothelial cells from their typical cobblestone appearance and their incorporation activity of acetylated low-density lipoprotein. For experimental use, the endothelial cells (passage levels under 20) were plated in 24-well dishes (Corning Glass Works, Corning, NY). Cells were plated in eight-well slide chambers (Nunc Inc., Herlev, Denmark) for PI stainings.

\section{Apoptosis}

Apoptosis was determined from the presence of nuclear fragmentation on PI staining. ${ }^{11}$ Cells were fixed with $70 \%$ alcohol for $10 \mathrm{~min}$ at $4^{\circ} \mathrm{C}$. After being washed with phosphate-buffered saline, the cells were treated with PI solution $(0.01 \mathrm{~g} / \mathrm{l})$ containing RNAse $(100 \mathrm{mg} / \mathrm{l})$ for $30 \mathrm{~min}$ at $37^{\circ} \mathrm{C}$. Following the incubation, the nuclear fragmentation (over 2) was observed using a fluorescence microscope (Nikon microphoto-FX, Nikon Japan Co., Tokyo, Japan), and cells (endothelial cells, 100 cells) were counted in 10 different fields chosen at random. The percentage of cells that underwent apoptosis was calculated using the formula: $\%$ apoptosis $=($ apoptotic cells $/$ total coun ted cells) $\times 100$.

\section{Viability assay}

Cell viability was evaluated using a 3-4,5-dime thylthiazol-2-yl-2,5-diphenylte trazolium bromide (MTT) assay. ${ }^{12}$ Briefly, endothelial cells were seeded into 96-well dishes (Corning). The cells were treated with TNFa $(1-10 \mathrm{ng} / \mathrm{ml})$ and cycloheximide $(10 \mu \mathrm{g} / \mathrm{ml})$ for $6 \mathrm{~h}$, and the MTT solution $(200 \mathrm{mg} / \mathrm{l})$ was then added. Thirty minutes later, dimethylsulfoxide was added to dissolve the cells. The fluorescence at $570 \mathrm{~nm}$ was measured. The cell survival rate was expressed according to the formula: \% survival rate $=[$ (test value - blank value $) /(\max$ imal value - blank value $)] \times 100$, where the blank value represents the cell-free dish, and the maximal value represents the fluorescence from the total cells.

\section{Statistical analysis}

Data are expressed as the mean \pm standard error of the mean (SEM). For comparisons of the mean values between two subsets of data, Student's $t$-test was used, employing the standard criterion of $P<0.01$ or $P<0.05$ to indicate statistically significant differences.

\section{Results}

\section{TNF $\alpha$-induced apoptosis of endothelial cells concomitantly with cycloheximide}

We examined the effect of TNF $\alpha(1-10 \mathrm{ng} / \mathrm{ml})$ on endothelial cells. Control endothelial cells displayed a typical cobblestone morphology, but their treatment with $1-10 \mathrm{ng} / \mathrm{ml}$ of TNFa for $6 \mathrm{~h}$ caused a little cell shrinkage. Concomitant treatment with TNFa $(1-10 \mathrm{ng} / \mathrm{ml})$ and cycloheximide $(10 \mu \mathrm{g} / \mathrm{ml})$ caused severe cell shrinkage for $6 \mathrm{~h}$. To determine whether the cell damage was due to apoptosis or not, we staine d the cells with propidium iodide. The nuclei of the control endothelial cells were round, whereas the TNF $\alpha(10 \mathrm{ng} / \mathrm{ml})$ and cycloheximide $(10 \mu \mathrm{g} / \mathrm{ml})$ tre ated cells revealed nuclei that were fragmented. The dose dependency of the TNF $\alpha$ effect on the apoptosis is illustrated in Fig. 1. Cycloheximide $(10 \mu \mathrm{g} / \mathrm{ml})$ given alone affected neither the morphology nor the apoptosis induction (Fig. 1).

\section{Prevention by the NF-KB inhibitor, PDTC, of TNF $\alpha$ and cycloheximide-induced apoptosis of endothelial cells}

Concomitant treatment of endothelial cells with PDTC ( $1 \mathrm{mmol} / \mathrm{l})$ completely inhibited the TNF $\alpha$ and cycloheximide-induced morphological changes, and 


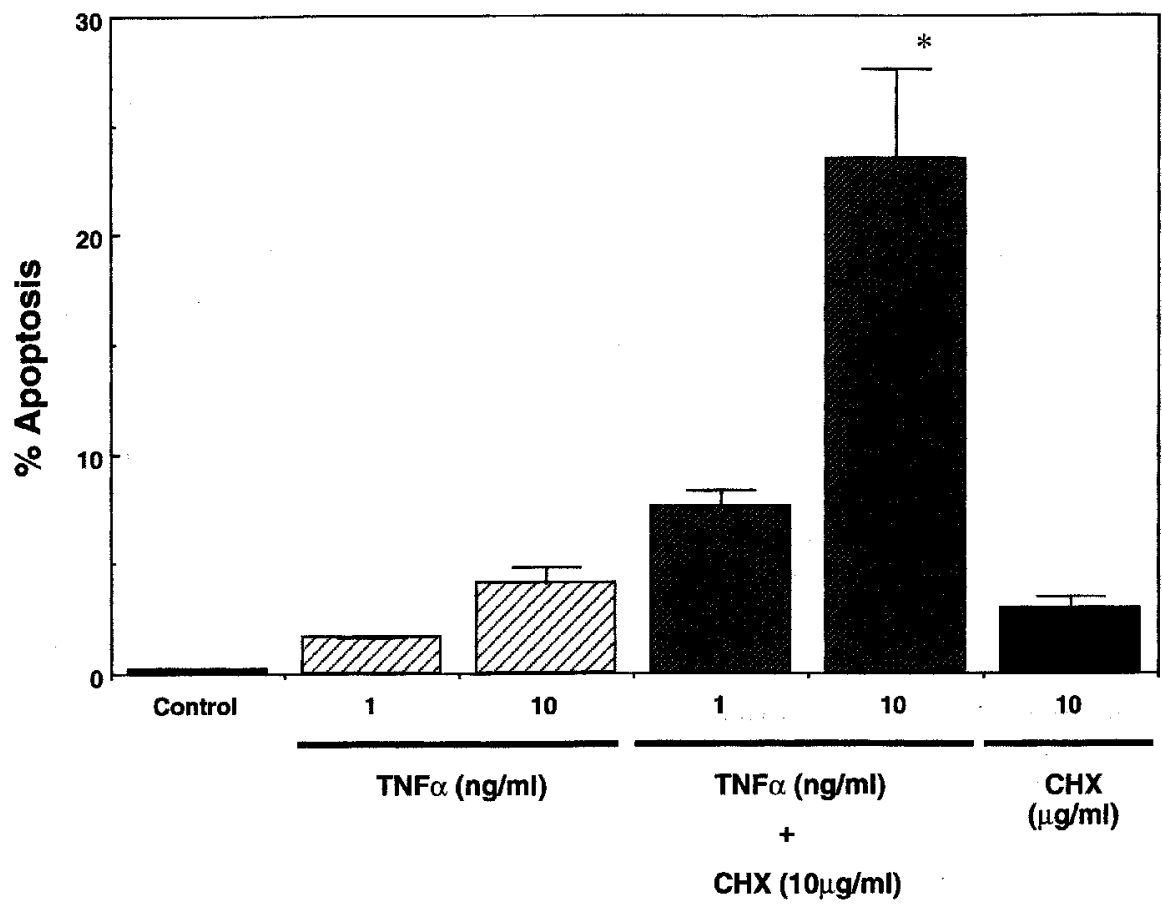

FIG. 1. Apoptosis of endothelial cells treated with TNF $\alpha$ and cycloheximide. Endothelial cell monolayers were treated with $1-10 \mathrm{ng} / \mathrm{ml} \mathrm{TNF} \alpha$ in the presence or absence of cycloheximide (CHX) $(10 \mu \mathrm{g} / \mathrm{ml})$ for $6 \mathrm{~h}$. After the incubation treatment, the cells were stained with $\mathrm{PI}$, as described in Materials and methods. The percentage of apoptotic endothelial cells represents the number of apoptotic cells in the counted 100 cells (apoptotic cells + viable cells). The data show the mean \pm SEM for 10 wells. * $P<0.05$ versus TNF $\alpha$-treated group. Each experiment was repeated three times.
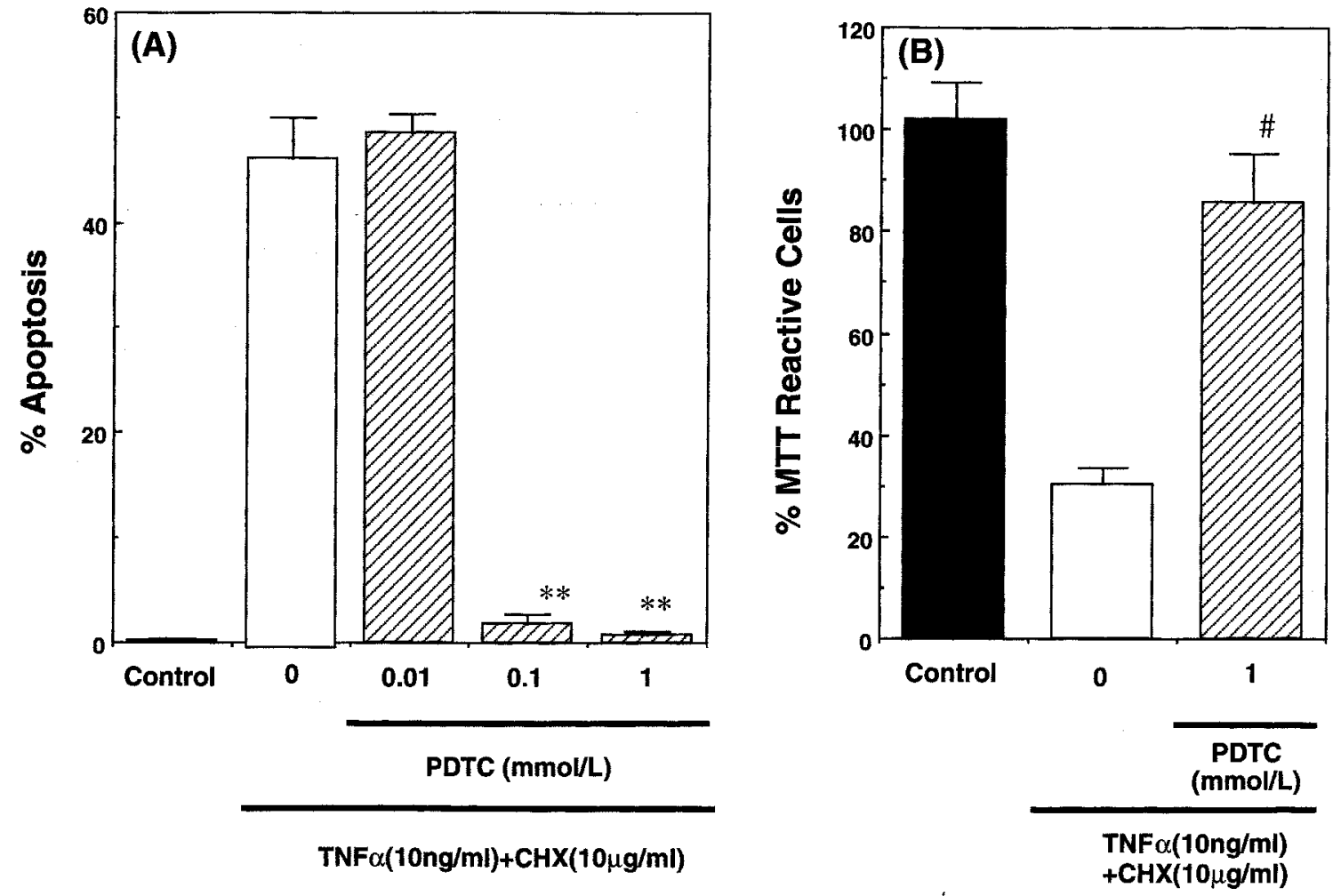

FIG. 2. PDTC-inhibited TNF $\alpha$ and cycloheximide-induced apoptosis of endothelial cells. (A) Endothelial cell monolayers were treated with TNF $\alpha(10 \mathrm{ng} / \mathrm{ml})$ and cycloheximide $(10 \mu \mathrm{g} / \mathrm{ml})$ in various concentrations of PDTC $(0-1 \mathrm{mmol} / \mathrm{l})$ for $6 \mathrm{~h}$. After the incubation treatment, the cells were stained with propidium iodide, as described in Materials and methods. ${ }^{*} P<0.01$ versus TNF $\alpha$ and cycloheximide-treated group. Each experiment was repeated three times. (B) Endothelial cell monolayers were treated with TNF $\alpha(10 \mathrm{ng} / \mathrm{ml})$ and cycloheximide $(10 \mu \mathrm{g} / \mathrm{ml})$ in the presence or absence of PDTC $(1 \mathrm{mmol} / \mathrm{l})$ for $6 \mathrm{~h}$. After the incubation treatment, the cells were stained with MTT, as described in Materials and methods. The data show the mean \pm SEM for eight wells. ${ }^{\#} P<0.05$ versus TNF $\alpha$ and cycloheximide-treated group. Each experiment was repeated three times. 


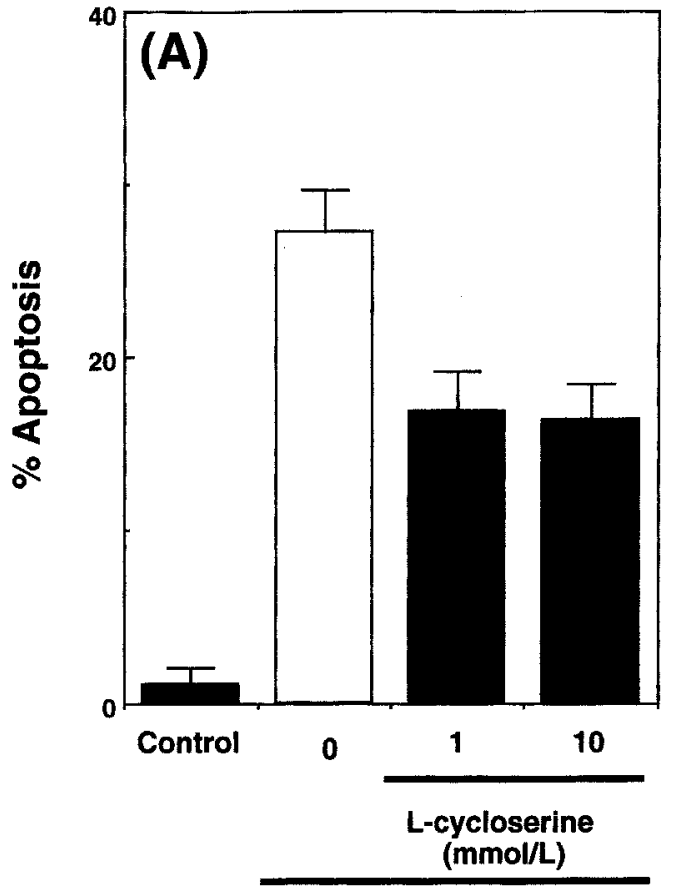

TNF $\alpha(10 \mathrm{ng} / \mathrm{ml})+\mathrm{CHX}(10 \mu \mathrm{g} / \mathrm{ml})$

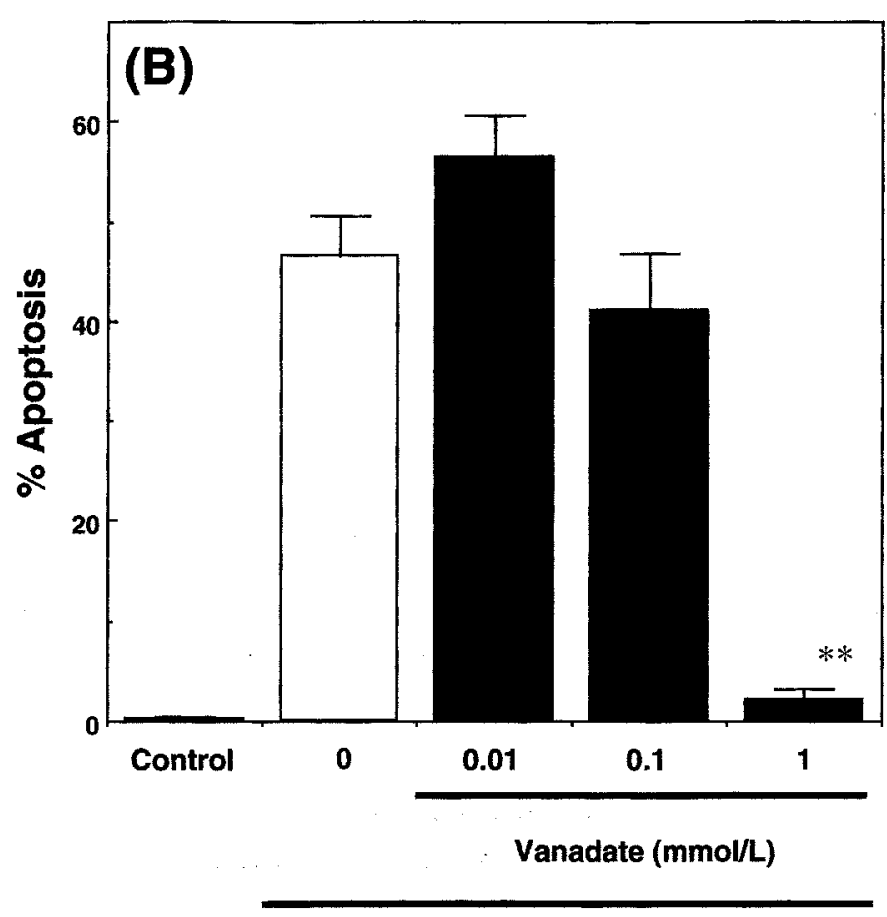

$\operatorname{TNF} \alpha(10 \mathrm{ng} / \mathrm{ml})+\mathrm{CHX}(10 \mu \mathrm{g} / \mathrm{ml})$

FIG. 3. Effects of L-cycloserine and vanadate on TNF $\alpha$ and cycloheximide-induced apoptosis of endothelial cells. (A) Endothelial cell monolayers were treated with TNF $\alpha(10 \mathrm{ng} / \mathrm{ml})$ and cycloheximide $(10 \mu \mathrm{g} / \mathrm{ml})$ in the presence or absence of L-cycloserine $(1-10 \mathrm{mmol} / \mathrm{l})$ for $6 \mathrm{~h}$. After the incubation treatment, the cells were stained with propidium iodide, as described in Materials and methods. The percentage of apoptotic endothelial cells represents the number of apoptotic cells in the counted 100 cells (apoptotic cells+viable cells). The data show the mean \pm SEM for 10 wells. (B) Endothelial cell monolayers were treated with TNF $\alpha(10 \mathrm{ng} / \mathrm{ml})$ and cycloheximide $(10 \mu \mathrm{g} / \mathrm{ml})$ in the presence or absence of sodium vanadate $(0.01-1 \mathrm{mmol} / \mathrm{l})$ for $6 \mathrm{~h}$. After the incubation treatment, the cells were stained with propidium iodide, as described in Materials and methods. The percentage of apoptotic endothelial cells represents the number of apoptotic cells in the counted 100 cells (apoptotic cells+viable cells). The data show the mean \pm SEM for 10 wells. ${ }^{*} P<0.01$ versus TNF $\alpha$ and cycloheximide-treated value. Each experiment was repeated three times.

nuclear fragmentation of the cells, as demonstrated in Fig. 2A. PDTC ( $1 \mathrm{mmol} / \mathrm{l})$ given alone affected neither the morphology nor the apoptosis induction. PDTC suppressed the TNF $\alpha$ and cycloheximide-induced endothelial cell apoptosis in a dose-dependent manner, as shown in Fig. 2A. PDTC also reversed the decreased survival rate caused by TNF $\alpha$ and cycloheximide in a dose-dependent manner (Fig. 2B). PDTC given alone did not influence the cell survival rate.

$\mathrm{NAC}$, another inhibitor of NF-KB, did not suppress the TNF $\alpha$ and cycloheximide-induced apoptosis (NAC $1 \mathrm{mmol} / \mathrm{l}$; \% inhibition $=0.3 \pm 4.0 \%$ ).

Effect of the sphigomyelinase inhibitor, L-cycloserine, and the tyrosine phosphatase inhibitor, vanadate, on endothelial cell apoptosis induced by TNF $\alpha$ and cycloheximide

Concomitant treatment of endothelial cells with L-cycloserine (an inhibitor of sphingomyelinase, $1-10 \mathrm{mmol} / \mathrm{l})$ did not inhibit the TNFa and cycloheximide-induced nuclear fragmentation of the cells, as demonstrated in Fig. 3A. The phosphatase inhibitor, sodium vanadate $(1 \mathrm{mmol} / \mathrm{l})$, completely inhibited the
TNF $\alpha$ and cycloheximide-induced apoptosis, as show $\mathrm{n}$ in Fig. 3B.

Protective effect of the caspase inhibitor, zD-dcb, on endothelial cell apoptosis induced by TNF $\alpha$ and cycloheximide

Concomitant treatment of endothelial cells with $z \mathrm{D}$ $\mathrm{dcb}$ (a caspase inhibitor, $50 \mu \mathrm{mol} / \mathrm{l}$ ) comple tely inhibited the TNF $\alpha$ and cycloheximide-induced nuclear fragmentation of the cells, as demonstrated in Fig. 4A. zD-dcb suppressed the TNF $\alpha$ and cycloheximideinduced endothelial cell apoptosis in a dose-dependent manner, as shown in Fig. 4A. zD-dcb also reversed the decreased survival rate caused by the TNF $\alpha$ and cycloheximide in a dose-dependent manner (Fig. 4B).

\section{Effects of ion transport inhibitors on} endothelial cell apoptosis induced by TNF $\alpha$ and cycloheximide

Concomitant treatment of endothelial cells with DIDS (a chloride bicarbonate exchanger blocker, 


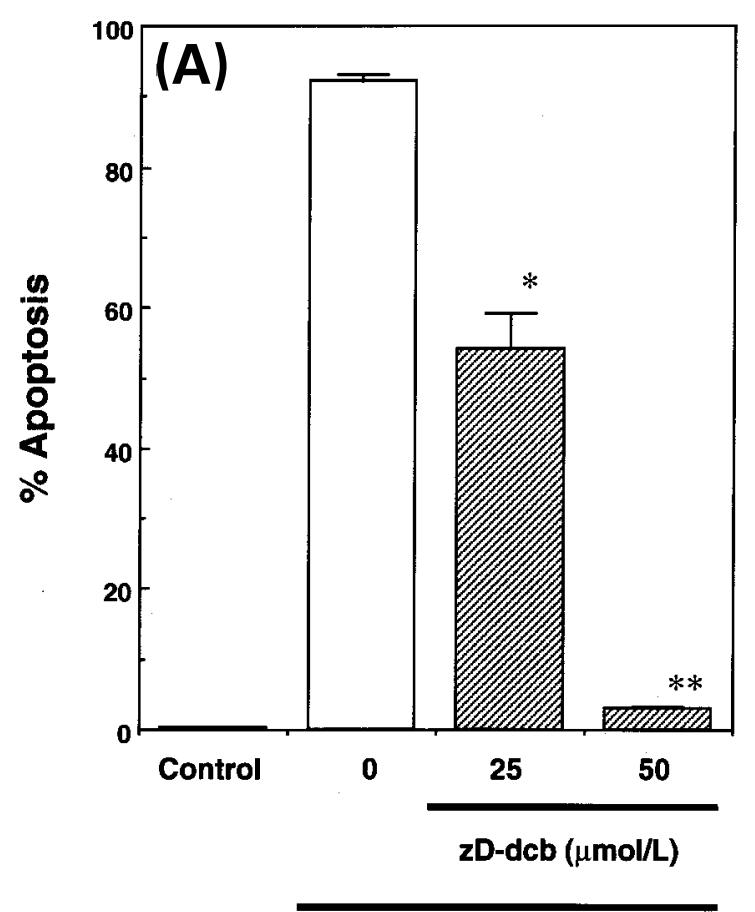

TNF $\alpha(10 \mathrm{ng} / \mathrm{ml})+\mathrm{CHX}(10 \mu \mathrm{g} / \mathrm{ml})$

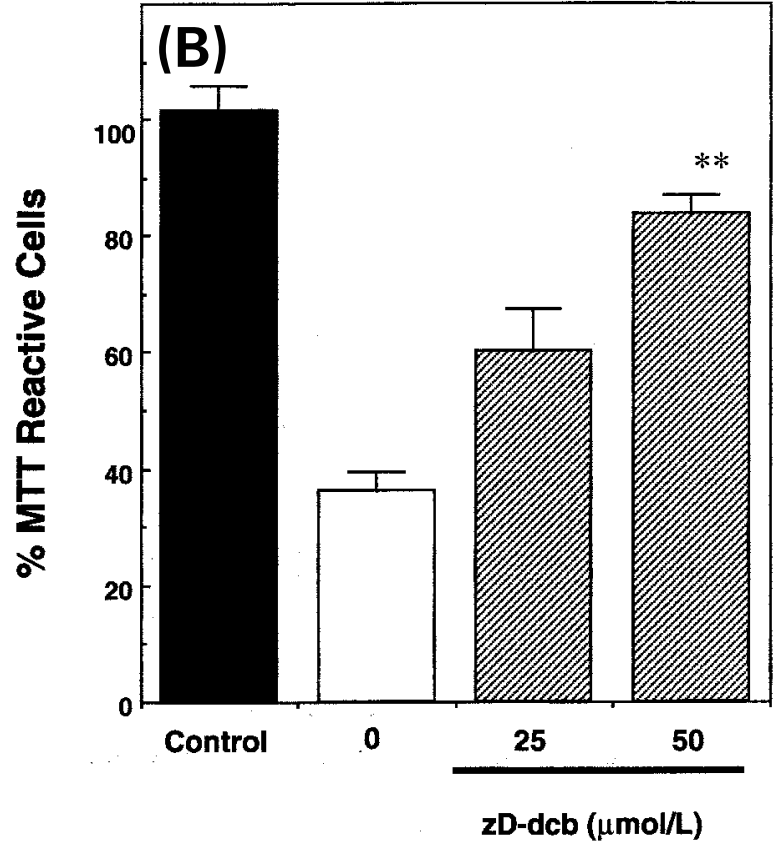

TNF $\alpha(10 \mathrm{ng} / \mathrm{ml})+\mathrm{CHX}(10 \mu \mathrm{g} / \mathrm{ml})$

FIG. 4. Effect of an inhibitor of caspase on TNF $\alpha$ and cycloheximide-induced apoptosis of endothelial cells. (A) Endothelial cell monolayers were treated with TNF $\alpha(10 \mathrm{ng} / \mathrm{ml})$ and cycloheximide $(10 \mu \mathrm{g} / \mathrm{ml})$ in the presence of various concentration of $\mathrm{zD}$ $\mathrm{dcb}$, an inhibitor of ICE $(0-50 \mu \mathrm{mol} / \mathrm{l})$, for $6 \mathrm{~h}$. After the incubation treatment, the cells were stained with $\mathrm{PI}$, as described in Materials and methods. ${ }^{*} P<0.05$ versus TNF $\alpha$ and cycloheximide-treated group; ${ }^{*} P<0.01$ versus TNF $\alpha$ and cycloheximidetreated group. Each experiment was repeated three times. (B) Endothelial cell monolayers were treated with TNF $\alpha(10 \mathrm{ng} / \mathrm{ml})$ and cycloheximide $(10 \mu \mathrm{g} / \mathrm{ml})$ in the presence of various concentration of $z D-d c b$, an inhibitor of caspase $(0-50 \mu \mathrm{mol} / \mathrm{l})$, for $6 \mathrm{~h}$. After the incubation treatment, the cells were stained with MTT, as described in Materials and methods. The data show the mean \pm SEM for eight wells. ${ }^{* *} P<0.01$ versus TNF $\alpha$ and cycloheximide-treated group. Each experiment was repeated three times.

$1 \mathrm{mmol} / \mathrm{l})$, in part, inhibited the TNFa and cycloheximide-induced nuclear fragmentation of the cells, as demonstrated in Fig. 5A. DIDS $(1 \mathrm{mmol} / \mathrm{l})$ given alone affected neither the morphology nor the apoptosis induction. DIDS suppressed the TNF $\alpha$ and cycloheximide-induced endothelial cell apoptosis in a dose-dependent manner, as shown in Fig. 5A. On the other hand, the sodium proton antiporter blocker, dimethyl amiloride $(0.1 \mathrm{mmol} / \mathrm{l})$, exerted no effect on the TNF $\alpha$ and cycloheximide-induced apoptosis (Fig. 5B). The chloride ion pump inhibitor, anthracene carboxylic acid $(1 \mathrm{mmol} / \mathrm{l})$, did not inhibit the TNF $\alpha$ and cycloheximide-induced apoptosis of endothelial cells (Fig. 5C).

\section{Discussion}

TNF $\alpha$ and cycloheximide-induced apoptosis of endothelial cells was due to NF-KB activation and was different from $T N F \alpha$-induced apoptosis

TNFa has been reported to be an inducer of apoptosis in some kinds of cells. This substance induced DNA laddering in tumor cells, and the cells displayed a typical morphological appearance of apoptosis. ${ }^{13}$ In the present study, we first demonstrated apoptosis due to TNF $\alpha$ in endothelial cells from the viewpoint of ion transport. Apoptosis of vascular endothelial cells may play an important role in the development of increased vascular permeability and capillary leak syndrome during systemic inflammatory response syndrome. Irradiation can also elicit a vascular permeability increase in rat lungs, resulting from apoptosis of the pulmonary endothelial cells as judged from the pathological findings. ${ }^{3}$ Recently, lupus anticoagulantinduced apoptosis of endothelial cells with recognition of annexin $\mathrm{V}$ has been reported. ${ }^{5}$ It was suggested that apoptosis of endothelial cells may be responsible for the vasculitis associated with syste mic lupus erythe matosus. The mechanis $m$ whereby TNFa induces apoptosis was not fully understood. Clarifying the mechanism will reach the goal to treat the vascular disease such as vasculitis. In general, it is known that TNF $\alpha$ elicited apoptosis through its receptor, ${ }^{6}$ subsequently stimulating the death domain, FADD, and activating caspase activity, resulting in apoptosis. ${ }^{6}$ On the other hand, TNF $\alpha$ also activates the sphyngomyelinase and produces the ceramide, which is capable of activating the kinase. 


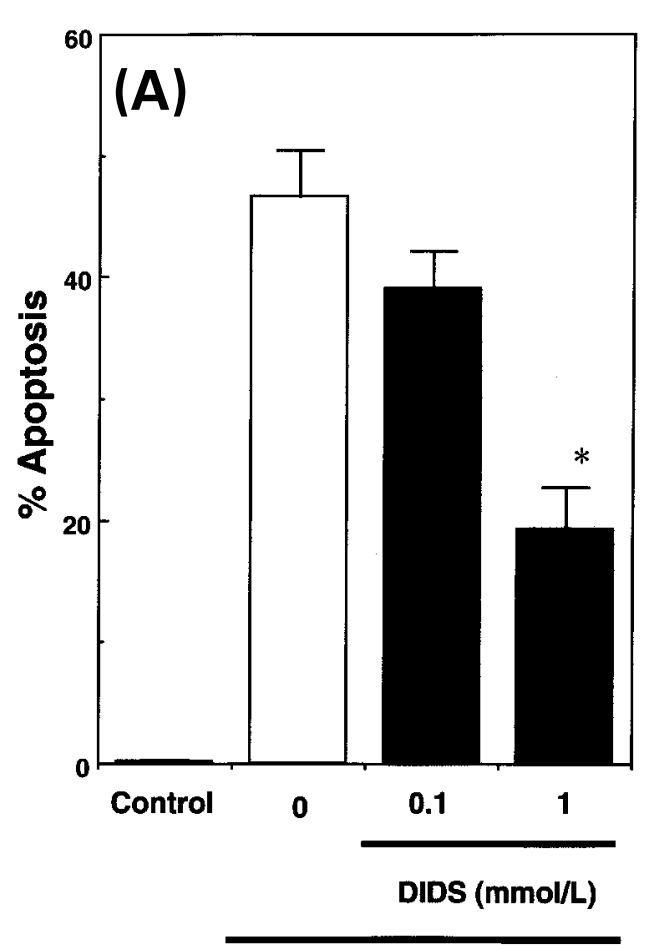

TNF $\alpha(10 \mathrm{ng} / \mathrm{ml})+\mathrm{CHX}(10 \mu \mathrm{g} / \mathrm{ml})$
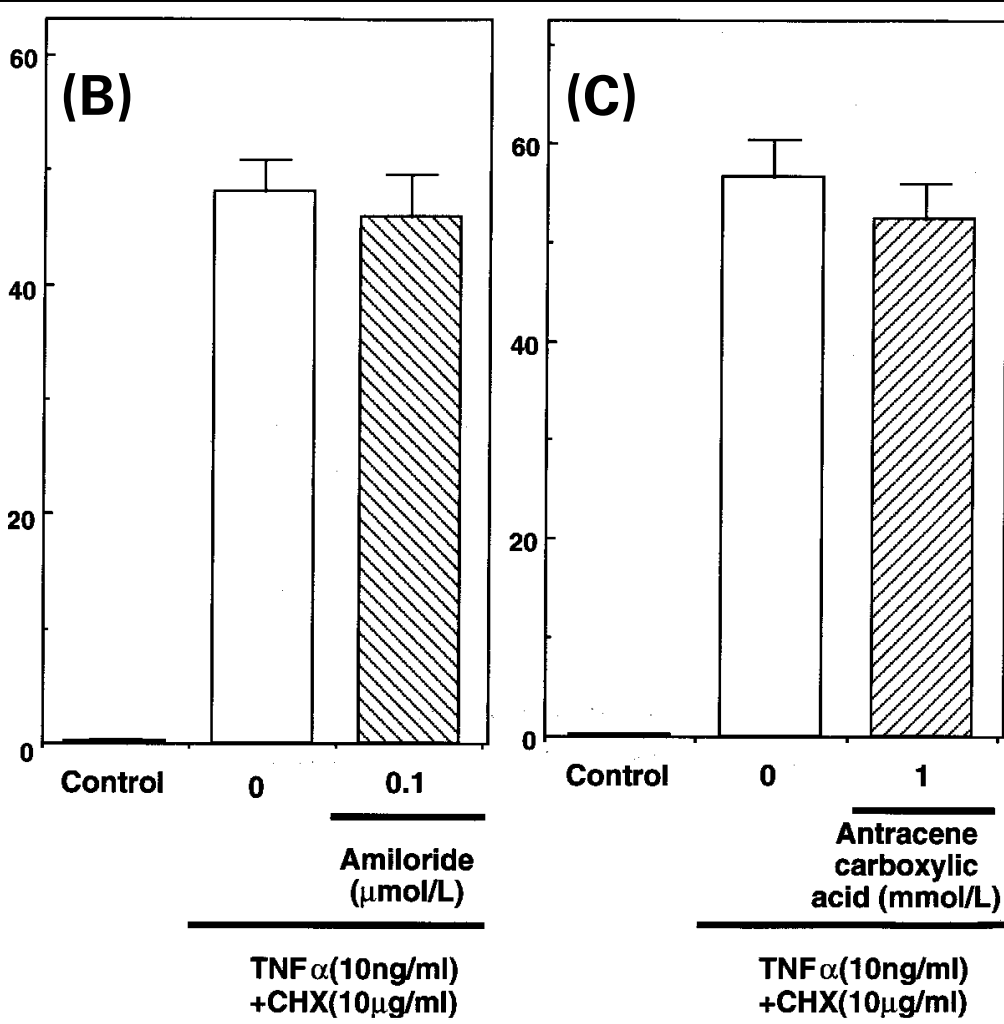

FIG. 5. Effects of various ion transporter inhibitors on TNF $\alpha$ and cycloheximide-induced apoptosis of endothelial cells. (A) Endothelial cells were treated with TNF $\alpha(10 \mathrm{ng} / \mathrm{ml})$ and cycloheximide $(10 \mu \mathrm{g} / \mathrm{ml})$ in the presence of various concentrations of DIDS $(0.1-1 \mathrm{mmol} / \mathrm{l})$ for $6 \mathrm{~h}$. After the incubation treatment, the cells were stained with propidium iodide, as described in Materials and methods. The percentage of apoptotic endothelial cells represents the number of apoptotic cells in the counted 100 cells (viable cells+apoptotic cells). The data show the mean \pm SEM for 10 wells. ${ }^{*} P<0.05$ versus TNF $\alpha$ and cycloheximidetreated group. Each experiment was repeated three times. (B) Endothelial cell monolayers were treated with TNF $\alpha(10 \mathrm{ng} / \mathrm{ml})$ and cycloheximide $(10 \mu \mathrm{g} / \mathrm{ml})$ in the presence of dimethyl amiloride $(0.1 \mu \mathrm{mol} / \mathrm{l})$ for $6 \mathrm{~h}$. After the incubation treatment, the cells were stained with PI, as described in Materials and methods. Each experiment was repeated three times. (C) Endothelial cell monolayers were treated with TNF $\alpha(10 \mathrm{ng} / \mathrm{ml})$ and cycloheximide $(10 \mu \mathrm{g} / \mathrm{ml})$ in the presence of anthracene carboxylic acid $(1 \mu \mathrm{mol} / \mathrm{l})$ for $6 \mathrm{~h}$. After the incubation treatment, the cells were stained with PI, as described in Materials and methods. Each experiment was repeated three times.

The ceramide-activating kinase stimulates NF-KB activation. ${ }^{8}$ TNFo-induced apoptosis through the FADD is independent on NF-KB activation. ${ }^{7}$ However, TNFa can induce apoptosis through the NF-KB activation in the concomitant presence of cycloheximide. ${ }^{14} \mathrm{We}$ checked the involvement of NF-KB in TNFa and cycloheximide-induced apoptosis (Fig. 2). In the endothelial cells from bovine carotid artery, TNF $\alpha$ and cycloheximide induced apoptosis through PDTCsensitive NF-KB (Fig. 2). How ever, another inhibitor of NF-KB, NAC, did not suppress the apoptosis induced by TNF $\alpha$ and cycloheximide. Bessho et al. also reported that etoposide-induced apoptosis of HL-60 cells and thymocytes was inhibited by PDTC, but not NAC. ${ }^{15}$ In our preliminary data, hydrogen peroxide and cycloheximide-induced apoptosis of endothelial cells was inhibited by either PDTC or NAC (data not shown). Thus, TNF $\alpha$ and cycloheximide-induced apoptosis is different from TNFo-induced apoptosis from the point of the involvement of NF-KB. Nevertheless, endothelial cell apoptosis induced by TNF $\alpha$ and cycloheximide as well as TNF $\alpha$ alone, is responsible for the caspase activation (Fig. 4).
On the other hand, the reason why cycloheximide enhances the TNF $\alpha$-induced apoptosis remains unclear. While TNF $\alpha$ directly causes apoptosis of tumor cells, normal cells are generally resistant. However, most resistant cells, including vascular endothelial cells, can be rendered susceptible to TNFo by inhibiting RNA and protein synthe sis. ${ }^{16}$ This suggests that TNF $\alpha$ provides a cell survival signal in addition to a death signal. Cell survival factors induced by TNF $\alpha$ are $\mathrm{BCl}-2$ analogue, A1, FGF-1 and nitric oxide (inducible nitric oxide synthase). ${ }^{17,18}$ Cycloheximide may inhibit the protein synthesis of their antiapoptotic factors and be able to easily enhance the TNFo-induced apoptosis.

\section{TNF $\alpha$ and cycloheximide-induced apoptosis was related to the tyrosine phosphatase, but not to the sphyngomyelinase}

TNFo also activates the sphyngomyelinase and produces the ceramide, which is capable of activating the kinase. The ceramide-activating kinase stimulates NF$\mathrm{\kappa B}$ activation. ${ }^{8}$ Nevertheless, TNF $\alpha$ and cyclohex- 
imide-induced apoptosis was not inhibited by an inhibitor of sphyngomyelinase (Fig. 3A), showing that the apoptosis was independent of the activation of sphingomyelinase through the TNF $\alpha$ receptor in our assay. Slowik et al. al3o reported that TNFo-induced apoptosis was not related to the ceramide through the sphingomyelinase activation. ${ }^{19,20}$ In addition, Modur et al. reported that ceramide production in the endothelial cells treated with TNFo did not activate NF-KB. ${ }^{21}$ These reports may suggest the agreement on our data.

Tyrosine kinase activation, as well as a grow th factor, is a survival factor. Tyrosine kinase inhibitors such as herbimysin or genistein caused the apoptosis of leukemic cells, which was rescued by the tyrosine phosphatase inhibitor, sodium vanadate. ${ }^{22,23}$ TNFa and cycloheximide-induced apoptosis was completely inhibited by sodium vanadate, as show $\mathrm{n}$ in Fig. 3B. The mechanis $m$ by which vanadate prevented endothelial cells from TNFo and cycloheximide-induced apoptosis is unclear. We speculate two possibilities: (1) vanadate may have an action on activation of tyrosine kinase, resulting in cell survival; (2) vanadate may cause a marked decrease in $\mathrm{p} 53$, the endogenous apoptotic inducer, as described by the previous report. ${ }^{24}$

\section{TNF $\alpha$ and cycloheximide-induced apoptosis was involved in the chloride bicarbonate exchanger}

In the present study, we attempted to use a blocker of chloride bicarbonate exchanger to inhibit TNF $\alpha$ and cycloheximide-induced apoptosis. In order to maintain cell shape, it is necessary to regulate the osmotic pressure and ion influx. We first considered the chloride channel, since this channel is responsible for regulation of the anionic properties and intracellular $\mathrm{pH}$. Moreover, chloride ion influx influences the shrinkage of cells. ${ }^{15} \mathrm{~A}$ chloride bicarbonate exchanger is present in various kinds of cells including ventricular myocytes, gastric cells, and renal tubular cells. ${ }^{26-28}$ DIDS, one of the chloride bicarbonate exchanger blockers, prevented TNF $\alpha$ and cycloheximide-induced apoptosis in endothelial cells. In addition, anthracene carboxylic acid, which inhibits the chloride influx via the blockade of chloride channel, did not affect the TNF $\alpha$ and cycloheximide-induced apoptosis (Fig. 5C). There is one possibility that TNFa and cycloheximide affect the function of the chloride bicarbonate exchanger, the reby eliciting a change in the intracellular chloride ion level as well as the intracellular bicarbonate level. Apoptosis could then be induced by chloride ion efflux, followed by a change in the intracellular $\mathrm{pH}$. In our unpublished data, DIDS inhibited the endothelial cell apoptosis and an increase in $\mathrm{pH}$, induced by staurosporine, another apoptosis inducer. Staurosporine changed the intracellular $\mathrm{pH}$ from 6.9 to 7.4 through a chloride bicarbonate exchanger (unpublished data). The change in $\mathrm{pH}$ does occur prior to the caspase activation (unpublished data). We speculate that endothelial cell apoptosis induced by TNF $\alpha$ and cycloheximide as well as staurosporine may be due to the activation of a chloride bicarbonate exchanger; chloride efflux and bicarbonate influx (an increase in $\mathrm{pH}$ ). We consider that $\mathrm{pH}$ change due to a chloride bicarbonate exchanger may be involved not in NF-KB activation, but caspase activation, although we have no direct proof. On other hand, Li and Eastman ${ }^{29}$ demonstrated that interleukin-2-stimulated lymphocytes induced apoptosis of target cells via intrac ellular acidosis through the sodium proton transporter. We speculate, therefore, that one of the common pathways of apoptosis may be via a sodium proton transporter. However, the sodium proton transporter blocker, dimethyl amiloride, did not affect the TNFa and cycloheximide-induced apoptosis (Fig. 5B). In our assay system, a sodium proton transporter was evidently not related to TNF $\alpha$ and cycloheximideinduced apoptosis.

Currently, we are attempting to elucidate more precisely the mechanism responsible for the apoptosis, which is related to various ion pumps, including an examination of the role of chloride ion and intrac ellular $\mathrm{pH}$.

\section{References}

1. Raff MC. Social controls on cell survival and cell death. Science 1992 356: 397-400.

2. Gottlieb RA, Burle son KO, Kloner RA, Babior BM, Engler RL. Reperfusion injury induces apoptosis in rabbit cardiomyocytes. J Clin Invest 1994; 94: 1621-1628.

3. Fuks Z, Persaud RS, Alfieri A et al. Basic fibroblast grow th factor protects endothelial cells against radiation-induced programmed cell death in vitro and in vivo. Cancer Res 1994; 54: 2582-2590.

4. Araki S, Shimada Y, Kaji K, Hayashi H. Role of protein kinase C in the inhibition by fibroblast grow th factor of apoptosis in serum-depleted endothelial cells. Biochem Biophys Res Commun 1990; 172: 1081-1085.

5. Nakamura N, Shidara Y, Kawaguchi N et al. Lupus anticoagulant autoantibody induces apoptosis in umbilical vein endothelial cells. Biochem Biophys Res Commun 1994; 205: 1488-1493.

6. Boldin MP, Goncharov TM, Goltsev YV, Wallach D. Involve ment of MACH, a novel MOLT-1/FADD-interacting protease, in Fas/Apo-1 and TNF receptor-induced apoptosis. Cell 1996; 85: 803-815.

7. Liu ZG, Hsu H, Goeddel DV, Karin M. Dissection of TNF receptor 1 effecter functions: JNK activation is not linked to apoptosis while NFkappa B activation prevents cell death. Cell 1996; 87: 565-576.

8. Kitajima I, Soejima Y, Takasaki I, Beppu H, Tokioka T, Maruyama I. Ceramide-induced nuclear translocation of NF-kappa B is a potential mediator of the apoptotic response to TNF-alpha in murine clonal osteoblasts. Bone 1996; 19: 263-270.

9. Mashima T, Naito M, Kataoka S, Kaw ai H, Hayashi H. Identification of actin as a substrate of ICE and an ICE-like prote ase and involvement of an ICE-like protease but not ICE in VP-16 induced U937 apoptosis. Biochem Biophys Res Commun 1995; 217: 1185-1192.

10. Fujita H, Morita I, Murota S. A possible mechanism for vascular endothelial cell injury elicited by activated leukocytes. Arch Biochem Biophys 1994; 309: 62-69.

11. WeiYQ, Zhao X, Kariya Y, Fukuta H, Teshigaw ara K, Uchida A. Induction of apoptosis by quercetin. Cancer Res 1994; 54: 4952-4957.

12. Mosmann T. Rapid calorimetric assay for cellular grow th and survival. $J$ Im munol Methods 1983; 65: 55-63.

13. Wang CY, Mayo NW, Baldwin AS. TNF and cancer therapy-induced apoptosis. Science 1996; 274: 784-787

14. Polunovsky VA, Wendt CH, Ingbar DH, Peterson MS, Bitterman PB. Induction of endothelial cell apoptosis by TNF alpha: modulation by inhibitors of protein synthesis. Exp Cell Res 1994; 214: 584-594. 
15. Bessho R, Matsubara K, Kubota M, Lin YW, Okuda A, Nishimori R. Pyrrolidine dithiocarbamate, a potent of nuclear factor kappa B activation, prevents apoptosis in human promyelocytic leukemia HL60 cells and thymocytes. Biochem Pharmacol 1994; 48: 1883-1889.

16. Karsan A, Yee E, Harlan JM. Endothelial cell death induced by tumor necrosis factor-alpha is inhibited by the Bcl-2 family member, A1. J Biol Chem 1996; 271: 27201-27204.

17. Maier JA, Morelli D, Menard S, Colnaghi MI, Balsari A. Tumor necrosis factor-induced fibroblast grow th factor-1 acts as a survival factor in a transformed endothelial cell line. Am J Pathol 1996; 149 945-952.

18. Dimmeler S, Haendeler J, Nehls M, Zeiher AM. Suppression of apoptosis by nitric oxide via inhibition of interleukin 1 beta converting enzyme like and cysteine protease protein 32 like proteases. J Exp Med 1997; 185: 601-607.

19. Slowik MR, De Luca LG, Min W, Pober JS. Ceramide is not a signal for tumor necrosis factor-induced gene expression but does cause programmed cell death in human vascular endothelial cells. Circ Res 1996; 79: 736-747.

20. Slowik MR, Min W, Ardito T, Kars an A, Kashgariam M, Pober JS. Evidence that tumor necrosis factor triggers apoptosis in human endothelial cells by interleukin 1 converting enzyme like protease-dependent and independent pathw ays. Lab Invest 1997; 77: 257-267.

21. Modur V, Zimmermann GA, Prescott SM, McIntyre TM. Endothelial cell inflammatory responses to tumor necrosis factor alpha. Ceramidedependent and independent mitogen-activated prote in kinase cascades. J Biol Chem 1996; 271: 13094-13102.
22. Bergamaschi G, Rosti V, Danova M, Ponchio L, Lucotti C, Cazzola M. Inhibitors of tyrosine phosphorylation induce apoptosis in human leukemic cell lines. Leukemia 1993; 7: 2012-2018.

23. Min A, Hasuma T, Yano Y, Matsui-Yussa I, Otani S. Regulation of apoptos is of interleukin 2-dependent mouse T-cell line by protein tyrosine phosphorylation and polyamines. J Cell Physiol 1995; 165: 615-623.

24. Chen ZP, Ye ung DC. Regulation of p53 expression in HeLa cells. Biochem Mol Biol Int 1996; 38: 607-616.

25. Widdas WF, Baker GK. The $\mathrm{pH}$ volume changes of human red cells in vitro due to the exchange of chloride and hydroxyl anions. Cytobio 1992; 72: 139-152.

26. Xu P, Spitzer KW. Na-independent $\mathrm{Cl}^{-}-\mathrm{HCO}_{3}^{-}$exchanger mediates recovery of $\mathrm{pH}_{\mathrm{i}}$ from alkalosis in guinea pig ventricular myocytes. $\mathrm{Am} J$ Physiol 1993; 267: H85-H91.

27. Horie S, Yano S, Watanabe K. Inhibition of gastric acid secretion in vivo and in vitro by an inhibitor of $\mathrm{Cl}^{-}-\mathrm{HCO}_{3}{ }^{-}$exchange $\mathrm{r}, 4,4^{\prime}$-diisothiocyanostilbene-2,2'-disulfonic acid. J Pharmacol Exp Theur 1993; 265: 1313-1318.

28. Weiner ID, Wingo CS, Hamm LL. Regulation if intracellular pHin tw o cell populations of inner stripe of rabbit outer medullary collecting duct. $\mathrm{Am}$ J Physiol 1993; 265: 1313-1318.

29. Li J, Eastman A. Apoptosis in an interleukin-2-dependent cytotox ic T lymphocyte line is associated with intracellular acidification. J Biol Chem 1995; 270: 3203-3211.

\section{Received 2 August 1999;}

accepted 24 August 1999 


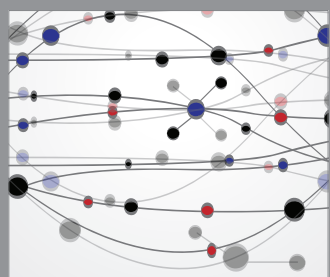

The Scientific World Journal
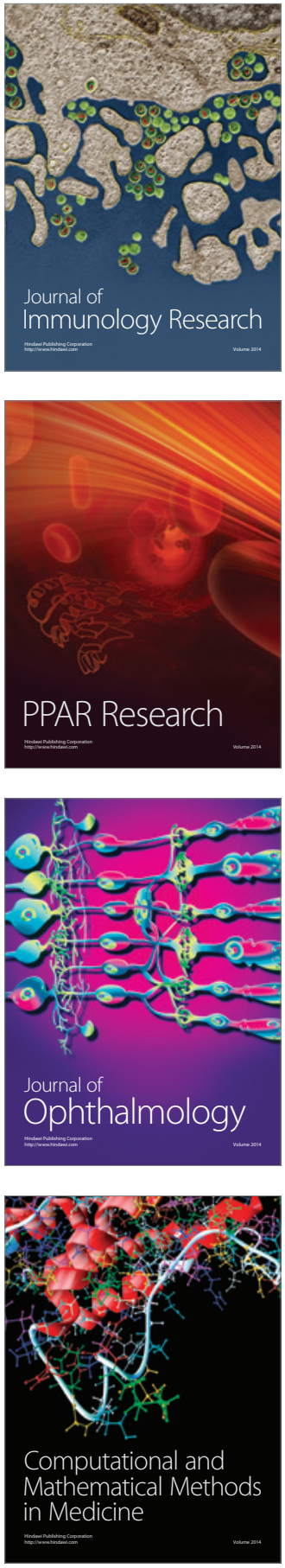

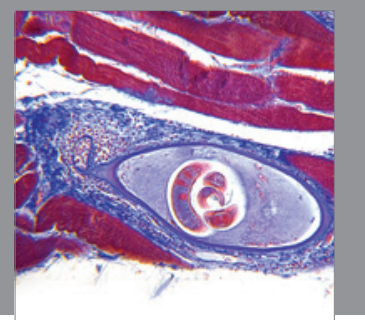

Gastroenterology

Research and Practice
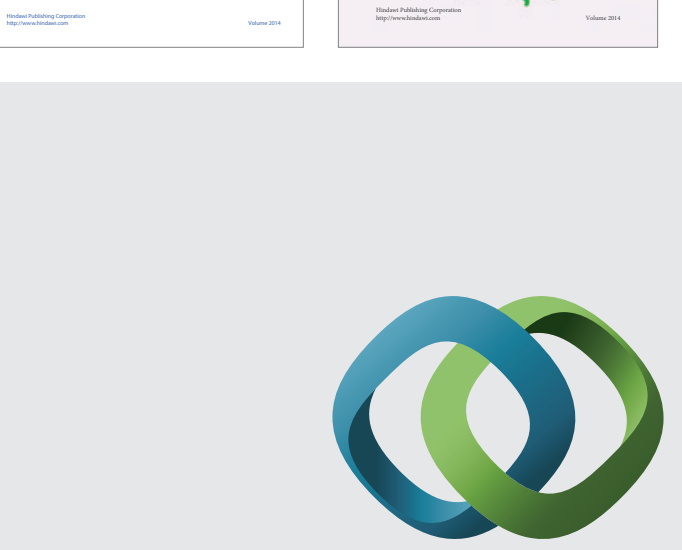

\section{Hindawi}

Submit your manuscripts at

http://www.hindawi.com
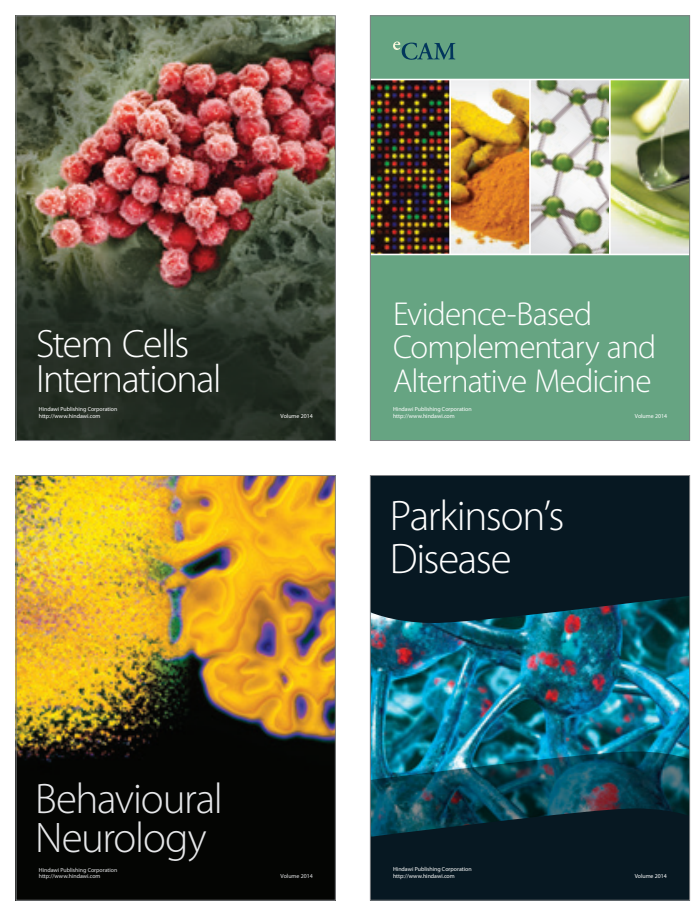

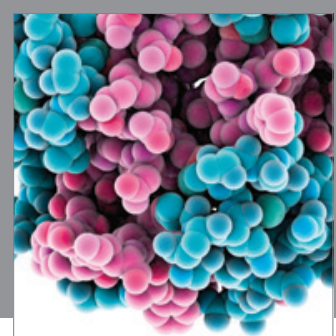

Journal of
Diabetes Research

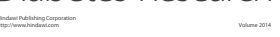

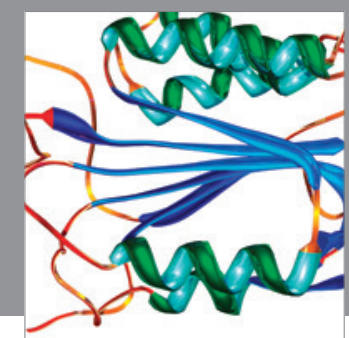

Disease Markers
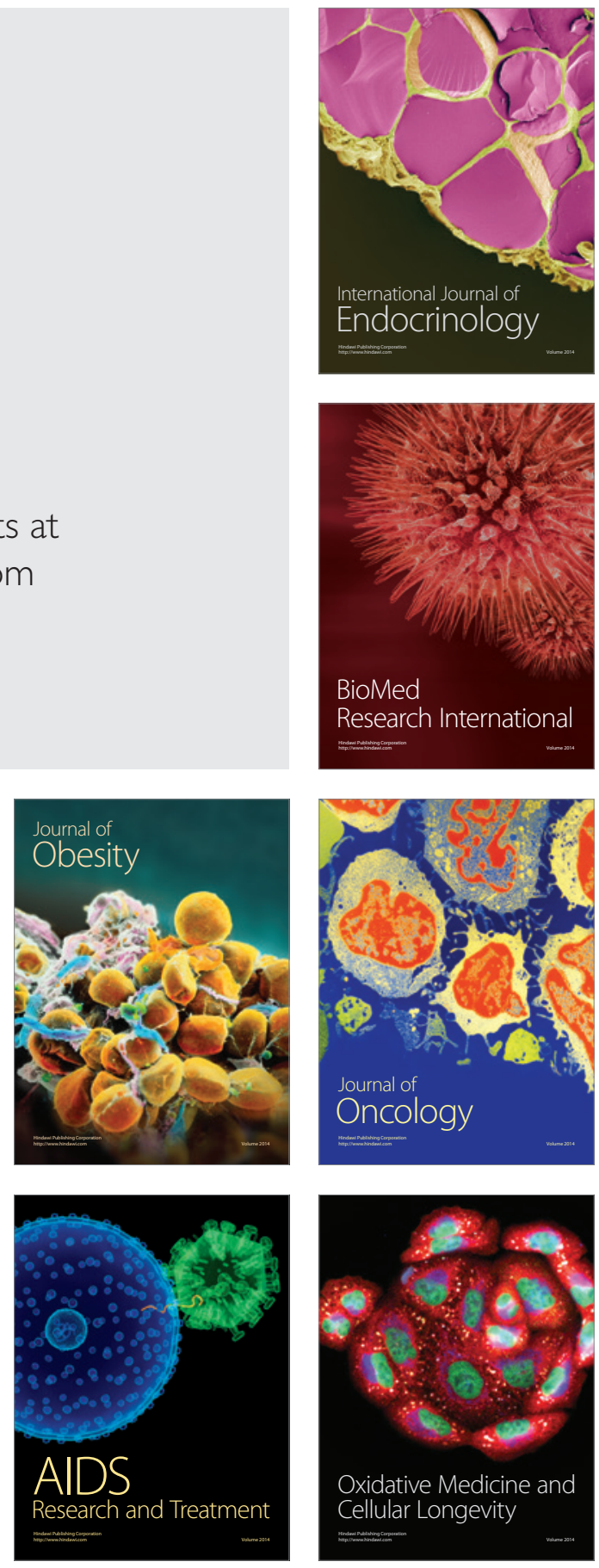